\title{
Leverage and Investment under a State-Owned Bank Lending Environment: Evidence from China
}

\author{
Michael Firth* \\ Department of Finance and Insurance \\ Lingnan University, Tuen Mun, Hong Kong, China \\ Tel: (852) 26168950 \\ Fax: (852) 24621073 \\ Email: mafirth@1n.edu.hk \\ Chen Lin \\ Department of Economics \\ Lingnan University, Tuen Mun, Hong Kong, China \\ Tel: (852) 26167200 \\ Fax: (852) 28917940 \\ Email: chen.lin@,ln.edu.hk \\ Sonia ML. Wong \\ Department of Finance and Insurance \\ Lingnan University, Tuen Mun, Hong Kong, China \\ Tel: (852) 26168159 \\ Fax: (852) 24621073 \\ Email: soniawong@ln.edu.hk
}




\title{
Leverage and Investment under a State-Owned Bank Lending Environment: Evidence from China
}

\begin{abstract}
This study examines the relations between leverage and investment in China's listed firms, where corporate debt is principally provided by stateowned banks. We obtain three major findings. First, there is a negative relation between leverage and investment. Second, the negative relation between leverage and investment is weaker in firms with low growth opportunities and poor operating performance than in firms with high growth opportunities and good operating performance. Third, the negative relation between leverage and investment is weaker in firms with a higher level of state shareholding than in firms with a lower level of state shareholding. Overall, our results are consistent with the hypothesis that the state-owned banks in China impose fewer restrictions on the capital expenditures of low growth and poorly performing firms and also firms with greater state ownership. This creates an over-investment bias in these firms.
\end{abstract}

Key Words: Capital Structure, Investment, State Ownership of Banks and Firms, China JEL Classification: G32 
Leverage and Investment under a State-Owned Bank Lending Environment: Evidence from China

\section{Introduction}

A significant but controversial issue in finance is the impact that leverage has on a firm's investment decisions. In a frictionless and complete markets world, Modigliani and Miller (1958) demonstrate that leverage is irrelevant to a firm's investment choices and to firm value. However, in a world where there are incomplete markets and significant agency costs, leverage may have a varied and complex impact on investment. For example, managers of highly levered firms may, in some circumstances, be induced to forego positive net present value (NPV) projects (Myers, 1977) because some or all of the benefits from the investment may accrue to debt-holders; this is known as the debt overhang problem and leads to underinvestment. Alternatively, Jensen (1986) and Stulz (1990) argue that high leverage in low growth firms is used to discourage management from undertaking non-profitable investments. Here, debt pre-commits firms to pay cash as interest and principal and such commitments in low growth firms can reduce managerial discretion over free cash flows that may have otherwise been allocated to negative NPV projects. In other words, the banks and other debt-holders perform a beneficial monitoring and disciplinary role in low growth firms where a high level of debt can limit the overinvestment bias caused by managerial agency problems.

In recent years empirical studies have been undertaken to examine the relevance of the leverage and capital investment theories. Lang et al. (1996), Aivazian et al. (2005), 
and Ahn et al. (2006) all report a negative relation between investment and leverage although the correlation is much stronger for firms with low growth. This evidence is consistent with the overinvestment story (Stulz, 1990) where leverage inhibits managers of low growth firms from investing in non-profitable capital expenditures. These studies use data from the U.S. and Canada where long-term debt finance is provided by profit maximizing banks and public bond markets. Here, the debt-holders monitor and discipline the firms they lend to. However, the results from these studies do not necessarily generalize to transitional economies where the relations between lenders and borrowers are more complex and subtle.

Transitional economies are characterized as having nascent stock markets, an absence of public debt markets (or, at most, embryonic public debt markets), and a reliance on bank borrowing. Furthermore, most banks are state owned and their decision making often reflects the policies dictated by government. Sapienza (2004), Khwaja and Mian (2005), and La Porta et al. (2002) argue that state-owned banks are controlled by politicians who use the banks to maximize their own political and personal objectives such as providing jobs for political supporters and bailing out poorly performing firms. In these cases, the banks' incentives to exert disciplinary pressures on firms are compromised. This could be particularly true for the poorly performing and loss making firms because the state-owned banks often have the obligation to support them (Cull and $\mathrm{Xu}, 2003$; Dobson and Kashyap, 2006). An investigation into the link between leverage and investment in an environment where banks are state owned can therefore provide a useful addition to the literature. Privately owned banks in developed countries generally use commercial criteria in making lending decisions although on some occasions political considerations may impinge on the decision process. In transitional or emerging economies where banks are owned by the state, political considerations are likely to weigh very heavily on lending policies.

The purpose of this study is to investigate the relations among investment, 
leverage, growth, and performance for China's listed firms. We use data from 1991 to 2004. The opening up of China's economy and the adoption of free market principles has presented many investment opportunities for its listed firms. The mean annual net investment by firms exceeds $34 \%$ of total assets in place at the beginning of the year and this helps account for China's staggering economic growth rate in the past 20 years. The public corporate bond market is extremely small in China and most borrowing comes from banks. According to Barth et al.'s (2004) dataset on bank supervision and regulation in 152 countries, more than $98 \%$ of the banking assets in China are owned and controlled by the state. The homogeneity of bank ownership in the country allows us to treat all bank loans carried on the listed firms' balance sheets as loans obtained from state-owned banks. In addition, nearly all China's listed firms are either directly controlled or ultimately owned by the state through pyramid structures (Liu and Sun, 2003). As state owned banks very often display similar biases in their lending to state-owned firms (Allen et al. 2005; Brandt and Li, 2003; Cull and Xu, 2003), the homogeneity of bank and firm ownership makes China an excellent context to test the link between a firm's investment and the debt financing provided by the state-controlled banks.

Our empirical analysis yields three major results. First, there is a negative relation between leverage and investment. This result is consistent with the existence of a debt overhang problem even when banks are state owned rather than privately owned. This result suggests that loans from state-owned banks are not an entirely free resource but are real financial obligations that listed firms must take into consideration. Second, the negative relation between leverage and investment is weaker in firms with low growth opportunities and poor operating performance than in firms with high growth opportunities and good operating performance. This result is in direct contrast to the evidence in the U.S. where low growth firms find it difficult to borrow money to finance expansion. Third, the negative relation between leverage and investment is weaker in firms with a higher level of state shareholding than in firms with a lower level of state 
shareholding. Overall, our results are consistent with the hypothesis that the state-owned banks in China impose fewer constraints on capital spending by low growth and poorly performing firms and firms with greater state ownership.

It is possible that leverage could be optimally reduced by management just prior to investing in valuable ex post growth opportunities. This implies a potential endogeneity problem because managers may reduce leverage in anticipation of future investment opportunities (Aivazian et al., 2005). However, most studies (e.g., Lang et al., 1996) use pooled OLS which does not take the individual firm effect and potential endogeneity into account. In this study, we follow Aivazian et al. (2005) and use fixed effects and instrumental variables analyses to adjust for the individual firm effect and to resolve the potential endogeneity problem.

Our study contributes to the several strands of research that make up the investment and leverage debate. Most empirical studies have used data from the U.S. and other developed countries that have a private, or quasi-private, banking sector. Using data from China allows us to analyze the investment and leverage relation in a state-controlled banking environment that differs quite markedly from those in other countries. Our results provide both supports for and against the findings from prior research.

First, we contribute to the empirical literature on the relation between leverage and investment. While existing studies find that a high level of corporate borrowing can limit the overinvestment bias in low growth firms due to the beneficial monitoring and disciplinary roles of private lenders (Lang et al. 1996; Aivazian et al. 2005; and Ahn et al. 2006), our study shows that the bail-out obligations of state-owned banks can weaken the disciplinary effects and create an overinvestment bias in the low growth and poorly performing firms. We believe that the evidence we present constitutes a useful extension to the literature, because state ownership of banks is common in countries other than the 
United States (La Porta et al 2002), and so our results can generalize.

We also extend the research field that examines how the banking environment affects corporate finance decisions. Based on the U.S banking markets, Zarutskie (2006) presents evidence that newly formed firms borrow and invest less after an increase in competition in the banking sector. These effects, however, gradually weaken as firms get older and finally reverse sign. After the government reduced its interventions in the banking sector, Bertrand et al. (2007) find evidence that French banks are less willing to bail out poorly performing firms, and those firms that rely on bank finance are more willing to undertake restructuring activities. Cetorelli (2004) shows that enhanced competition in the EU banking system fosters the emergence and development of small firms. Similarly, Beck et al. (2004) offer international evidence that more banking competition is associated with fewer financial obstacles for small firms. Most recently, González and González (2008) show that firm leverage increases with greater bank concentration and stronger protection of creditor rights based on a sample of firms cross 39 countries. While studies in this strand of literature focus on the degree of competition in the banking sector, our study examines a new dimension of the banking environment the ownership nature of the banks. We show that, under the state ownership of banks, corporate investment will be affected not only by firm-specific economic and financial factors but also the banks' politically-determined lending policies. In our case, the low growth and poorly performing firms as well as firms with a higher state ownership stake tend to have a higher level of investment due to the more lenient lending policies of banks. As far as we aware, the evidence we present on the implication of bank ownership on corporate investment has not been documented by the prior studies.

Our study also relates to the literature on the roles of corporate debt as an instrument 
of corporate governance. Corporate finance theories suggest that creditors, including commercial banks and trade credit suppliers, have the incentives and capacity to discipline poorly performing managers (Jensen and Meckling, 1976; Diamond, 1984). Kang and Shivdasani (1995), for example, find that Japanese firms with close ties to a main bank demonstrate a higher incidence of CEO turnover in response to poor performance than firms that do not have such a relationship. Based on the analysis of the market reactions to more than 800 loan announcements, Byers et al. (2008) show that these loan announcements are more likely to be associated with positive wealth effects for firms with weak internal and external corporate governance. Thus, corporate borrowing leads to closer monitoring of the firm by the banks that provide the loans. All these studies suggest that commercial banks are able to perform a beneficial role in corporate governance. Some studies, however, show that there are agency costs of debt (particularly in high risk firms) due to the different payoff structures of shareholders and bondholders (Jensen and Meckling, 1976; Krosznera and Straham, 2001; Byrd and Mizruchi, 2005). Krosznera and Straham (2001) find that bankers only sit on the boards of firms when the conflicts of interests between shareholders and bondholders are low. Byrd and Mizruchi (2005) show that firms that have a banker on the board are associated with a lower debt ratio. Our findings complement these studies by offering evidence that bank lending in China reduces the negative links between leverage and investment in low growth and poorly performing firms. This in turn suggests that the disciplinary and monitoring roles of banks in low growth and poorly performing firms might have been compromised due to state-owned banks' obligations to bail these firms out.

At a practical level, our study provides useful information on the investment behaviors of China's listed firms and the lending behaviors of China's state-owned 
banks. This is clearly of interest to both policy makers and investors. For example, the results from our study may help policy makers to better assess the effects of reducing state intervention in the banking sector on the financing of industrial enterprises. If banks are fully privatized then they are likely to base their lending decisions primarily on commercial considerations. Even partially or fully state-owned banks will increasingly need to use commercial considerations so that they can compete with the influx of foreign banks that have arrived after the relaxation of entry barriers to the banking sector. Banks' uses of commercial considerations in lending decisions will likely lead to funding and liquidity crises for poorly performing firms.

The remainder of the paper is structured as follows. In the next section we provide a brief review of the related literature. The econometric models that we use are discussed in section 3. In section 4, empirical results and robustness checks are presented. Section 5 summarizes and concludes the paper.

\section{Related Literature}

Our study connects separate literatures that examine the links between leverage and investment, the lending behavior of state-owned banks, the evolution of China's banking sector and the ownership structure of China's listed firms. In this section, we review the previous literature and evidence in each of these streams of research. Our research contributes directly to each of the streams of research discussed below. At a basic level, we corroborate prior research on the link between investment and leverage. We then extend prior research by delving into the role of state-owned banks, policy leading, and ownership of firms.

\subsection{Prior Evidence on the Relation between Leverage and Investment}


As we discussed in the introduction, leverage may induce underinvestment in some circumstances because the benefits accrue, at least partially, to the creditors rather than accruing fully to the shareholders. On the other hand, leverage can alleviate the agency problem of investing in negative NPV projects by constraining "overinvestment" in low growth firms. The existing evidence from North America largely supports these implications. McConnell and Servaes (1995) show that the value of U.S. firms is negatively correlated with leverage for high growth firms (indicated by high Tobin's Q), and positively correlated with leverage for low growth firms (or low Tobin's Q). Lang et al. (1996) find a strong negative relation between leverage and subsequent investment, but only for firms with weak growth opportunities (with Tobin's Q less than one). Based on evidence from Canadian firms, Aivazian et al. (2005) also offer evidence for a significantly negative impact of leverage on investment, with the negative relation stronger for low growth firms. The results provide support to agency theories of corporate leverage, and especially the theory that leverage has played a disciplinary role for firms with low growth opportunities. Recently, Ahn et al. (2006) document that the negative relation between leverage and investment in diversified firms is significantly stronger for high Q segments than for low Q business segments, and is significantly stronger for non-core segments than for core segments. Among low growth firms, the positive relation between leverage and firm value is significantly weaker in diversified firms than in focused firms. Their results suggest that the disciplinary benefits of debt are partially offset by the additional managerial discretion in allocating debt service to different business segments within a diversified organizational structure.

\subsection{State-Owned Banks}

Private and state-owned banks tend to operate with different objectives; private banks primarily aim to maximize the returns on capital contributed by its shareholders while state-owned banks follow the objectives set by politicians and bureaucrats to serve 
political and personal objectives (Shleifer and Vishny, 1994; Sapienza, 2004; Dinc, 2005). Given the different objectives and incentive structures, private and state-owned banks tend to have different lending behaviors where loans are allocated and priced differently. While private banks tend to allocate and price loans according to borrowers' risk profiles, state-owned banks tend to allocate and price loans according to the preferences and priorities of governments. Several cross-country studies (e.g., La Porta et al., 2002) show that in countries with state-owned banks, the banks lend largely to state-owned enterprises (SOEs). Based on firm-level data, Sapienza (2004) finds that state-owned banks mostly favor large firms and firms located in depressed areas. Lending behavior is also affected by the party affiliated with the bank: the stronger the political party in the area where the firm is borrowing, the lower the interest rate charged. Dinc (2005) documents that state-owned banks increase their lending during election years, relative to the lending made by private banks. Bertrand et al. (2007), on the other hand, show that state-controlled French banks tend to provide subsidized loans to bail out poorly performing firms. As banks' allocation and pricing of loans have implications for firms' free cash flows and evaluations of projects, the ownership nature of the bank affects the relations between leverage and investment. Empirical evidence on the effect of leverage on investment under the state ownership of a bank therefore provides a useful addition to the literature.

\subsection{China’s Bank Sector and its Lending Behavior}

After more than two decades of economic transition where China has been gradually transformed into a market economy, China still manages to maintain dominant state ownership in her banking sector in order to channel bank deposits to the ailing SOEs (Allen et al., 2005; Dobson and Kashyap, 2006). As Dobson and Kashyap (2006) point out (p.117), "China's banking system still has the highest share of government ownership (almost 100 percent) in the world. The pessimistic interpretation, that the 
government is retaining ownership in order to preserve the option to direct credit, is reinforced by the fact that the government has done little to promote the development of a bond market. Instead virtually all debt financing in China is done through the banks". As support for the latter stylized fact, bank statistics show that although the private sector accounts for 50 percent of the economy it accounts for just 7 percent of bank lending. State-owned banks' obligations to lend to SOEs is widely regarded as a major cause of China's enormous level of non-performing bank loans. On the one hand, loss making or poorly performing SOEs are usually firms with poor fundamentals and thus inherently have a high default risk. On the other hand, the state-owned banks are also able to ignore the non-performing loans on the grounds that they were caused by their obligations to bailout the state-owned firms and therefore it is the central government who has to bear the final responsibility for the consequences. This provides state-owned banks with legitimate grounds to ignore the quality of loans, even though some of the bad loans are caused by a lack of due-diligence monitoring or corrupt behaviors on the part of bank officials rather than the policy lending itself. Consequently, banks in China have been saddled with extensive portfolios of non-performing loans. An official estimation of the non-performing loans of the "big four" banks as at the end of 2003 amounted to 2.4 trillion yuan (US\$ 290 billion), or 23\% of the total loans outstanding while the unofficial amount is even higher (about 3.5 trillion yuan) (The Economist, Dec. 4, 2003).

State-owned banks' policy lending not only leads to the accumulation of nonperforming loans but also distorts firms' investment decisions. Through the leverageinvestment link, it is argued that the policy lending of state-owned banks would eventually affect capital allocation efficiency and thus the economic growth of the economy (Dobson and Kashyap, 2006). Despite the importance of the topic, very few empirical studies have been carried out due to the problem of data availability. Brandt and $\operatorname{Li}$ (2003) show that China's state-owned banks discriminate against private firms in their lending decisions. Cull and $\mathrm{Xu}$ (2003) find that state banks have grown 
increasingly inefficient in allocating credit since the mid-1990s as they have been increasingly forced to bail out poorly performing SOEs. A recent paper has shown that, before 2001, there was a negative relationship between bank loans and firm profitability not only in SOEs but also in private firms (Cull et al., 2007). This suggests that the state owned banks might have offered a helping hand not only to the ailing SOEs but also private firms. Our study adds to the literature by using updated data and by exploring explicitly the impact of the banks' policy lending on firms' investment policies.

China's stock market was created as a fund-raising venue for SOEs (Wong, 2006). As a result, the majority of China's listed firms are controlled by state shareholders who retain their dominant control over the listed firms through their ownership of about two-thirds of the total equity in the form of non-tradable state-owned shares (Firth et al., 2006; Lin and $\mathrm{Su}, 2008$ ). We use the ownership structure of China's listed firms to help us to investigate how politically-motivated lending by state owned banks can affect the firms' leverage-investment link. In particular, the variations in the degree of state ownership enable us to examine whether the state owned banks treat stateowned firms more favorably in their lending decisions and how such distortion affects firm investment. The availability of detailed financial data also allows us to examine how the bail-out obligations of the state-owned banks affect firm investment. State owned banks in China have an additional incentive to bail out the poorly performing listed firms because a listed firm which has experienced losses for two consecutive years may face de-listing if it cannot return to profitability. In order to preserve the rights to equity financing, local governments in China have strong incentives to provide the loss making listed firms with bank loans and subsidies (Bai et al. 2003; Pistor and Xu, 2005).

\section{Model Specifications}

Following previous studies (Aivazian et al., 2005), we employ an investment equation to explore the impacts of bank loans on firm investment. Specifically, the 
model is expressed as follows.

Investment $_{\mathrm{t}, \mathrm{t}}=\beta_{0}+\beta_{1}$ Leverag $_{\mathrm{\varphi}, \mathrm{t}-1}+\beta_{2}$ Tobin's $_{\mathrm{i}, \mathrm{t}-1}+\beta_{3}$ DTobin's $_{\mathrm{i}, \mathrm{t}-1} \times$ Leverag $_{\mathrm{q}, \mathrm{t}-2}+\beta_{4}$ Cas $+\beta_{5}$ Sale $_{\mathrm{i}, \mathrm{t}-1}+\beta_{6}$ State $_{\mathrm{i}, \mathrm{t}}+\beta_{7}$ FirmSize $_{\mathrm{i}, \mathrm{t}}+$ TimeDummies $\lambda_{\mathrm{i}}+\varepsilon_{\mathrm{i}, \mathrm{t}}$

where Investment $_{i, t}$ is the ratio of net capital expenditure (capital expenditure minus depreciation) of firm i to total assets for the current year; Leverage $_{i t-1}$ is the lagged one time period ratio of total bank loans to book value of total assets. We use Tobin's Q as a measure of growth and performance. Tobin' $s Q_{i, t-1}$ is the lagged one time period Tobin'sQ for firm ${ }^{i}$ at time ${ }^{t}$; following previous studies (Chung and Pruitt, 1994), Tobin's is calculated as follows. Tobin's $=($ MVCS + BVPS + BVLTD + BVINV + BVCL - BVCA) / BVTA, where MVCS is the market value of the firm's common stock, BVPS is the book value of the firm's preferred stock, BVLTD is the book value of the firm's long-term debt, BVINV is the book value of the firm's inventories, BVCL is the book value of the firm's current liabilities, BVCA is the book value of the firm's current assets, and BVTA is the book value of the firm's total assets. Because no preferred stock exists in China, the above formula reduces to (MVCS + BVLTD + BVINV + BVCL BVCA) / BVTA. In addition, we adjust the measurement of Tobin's Q to take account of illiquidity discounts of $70 \%$ in the Chinese market (Chen and Xiong, 2002). Specifically, we multiply the amount of tradable shares by the market price and the amount of nontradable shares by $30 \%$ of the market share price to obtain the value of equity in the above formula. Consistent with the previous studies, we create a dummy variable, DTobin's $Q_{i, t-1}$, which equals 1 if Tobin' $^{\prime} Q_{i, t-1}$ is less than the industry median value in that year and zero otherwise.

We follow prior studies to control for firms' cash flow and sales conditions. CashFlow $_{i, t}$ is the ratio of the operating cash flow of the firm to lagged one time period 
total assets; it is a measure of a firm's profitability. Sale $_{i, t-1}$ is the lagged one time period ratio of net sales of the firm to net fixed assets. Other control variables such as state ownership, firm size, and firm age are included in the model. State $_{i, t}$ is the percentage of the state-owned shares in firm ${ }^{i}$ at time $t$; Firm Size $_{i, t}$ is measured by the natural logarithm of total assets; Firm Age $_{i, t}$ is the number of years since the firm went public. Time Dummies are used to capture the potential differences in the macroeconomic environment over the years.

Most previous studies (e.g., Lang et al., 1996; Ahn et al., 2006) assume that the unobservable individual firm effect is zero and use a pooled regression to estimate the investment function. As Aivazian et al. (2005) point out (p. 282), "the assumption of zero unobservable individual effect is too strong given that there is large heterogeneity across industries and across firms within the same industry." For instance, if a firm has a good political connection with government officials, the firm may find it relatively easy to get a bank loan and acquire valuable projects from the government. Therefore, ignoring the unobservable factors creates an endogeneity problem and makes the estimation results biased. In this study, we follow Aivazian et al. (2005) and use the firm fixed effect (demeaned estimation) panel regression estimation to eliminate the non-observed time invariant firm effect. ${ }^{\lambda}$ and $\varepsilon_{i, t}$ in Equation 1 refer to the individual firm fixed effect and the error term respectively.

There are potential problems in using market-based variables as growth and performance measures in emerging markets. For instance, since the stock market in China is far from being well developed, changes in stock prices may be poor indicators of changes in a firm's fundamental value (Allen et al., 2005). Morck et al. (2000) find that more than $80 \%$ of the stocks listed on the exchanges in China move in the same direction in a given week, which suggests that stock returns in China are less informative of firm performance than in developed economies, because they tend to reflect market-level information rather than firm-specific information. Hence, we use sales growth 
$\left(\right.$ Growth $\left._{i, t}\right)$, which is the ratio of net sales in the current year to the average net sales over the previous three years, to capture the growth prospect of a listed firm. If we use the sales growth as the performance measure, rather than Q, the model is expressed as follows.

Investment $_{\mathrm{i}, \mathrm{t}}=\beta_{0}+\beta_{1}$ Leverage $_{\mathrm{i}, \mathrm{t}-1}+\beta_{2}$ Growth $_{\mathrm{i}, \mathrm{t}}+\beta_{3}$ DGrowth $_{\mathrm{i}, \mathrm{t}} \times$ Leverage $_{\mathrm{i}, \mathrm{t}-1}+\beta_{4}$ CashF $+\beta_{5}$ Sale $_{i, t-1}+\beta_{6}$ State $_{i, t}+\beta_{7}$ Firm Size $_{i t}+$ Time Dummies $+\lambda_{i}+\varepsilon_{i, t}$

where DGrowth $_{i, t}$ is a dummy variable that equals 1 if Growth $_{i, t}$ is less than the industry median value in that year. The other variables are defined as previously.

We estimate two sets of models to explicitly examine two politically-motivated lending distortions introduced by China's state-owned banks, namely, bailing out of lossmaking firms and more lenient lending to state-owned firms. We estimate the following model to explore the bailing out effects:

$$
\begin{gathered}
\text { Investment }_{\mathrm{i}, \mathrm{t}}=\beta_{0}+\beta_{1} \text { Leverage }_{\mathrm{i}, \mathrm{t}-1}+\beta_{2} \text { CashFlow }_{\mathrm{i}, \mathrm{t}}+\beta_{3} \text { DLoss }_{\mathrm{i}, \mathrm{t}} \times \text { Leverage }_{\mathrm{i}, \mathrm{t}-1} \\
+\beta_{4} \text { Sale }_{\mathrm{i}, \mathrm{t}-1}+\beta_{5} \text { State }_{\mathrm{i}, \mathrm{t}}+\beta_{6} \text { FirmSize }_{\mathrm{it}}+\text { Time Dummies }+\lambda_{\mathrm{i}}+\varepsilon_{\mathrm{i}, \mathrm{t}}
\end{gathered}
$$

where DLoss $_{i, t}$ is a dummy variable that equals 1 if a firm is loss making (CashFlow ${ }_{i, t}$ is negative) in that year. A positive coefficient on the interaction term between $D L O S s_{i, t}$ and Leverage $_{i t-1}$ will be consistent with our hypothesis that state owned banks impose fewer investment restrictions on low growth (more poorly performing) firms.

To examine the positive lending bias to state-owned firms, the following model is used:

$$
\begin{gathered}
\text { Investment }_{\mathrm{i}, \mathrm{t}}=\beta_{0}+\beta_{1} \text { Leverage }_{\mathrm{i}, \mathrm{t}-1}+\beta_{2} \text { CashFlow }_{\mathrm{i}, \mathrm{t}}+\beta_{3} \text { DState }_{\mathrm{i}, \mathrm{t}} \times \text { Leverage }_{\mathrm{i}, \mathrm{t}-1} \\
+\beta_{4} \text { Sale }_{\mathrm{i}, \mathrm{t}-1}+\beta_{5} \text { State }_{\mathrm{i}, \mathrm{t}}+\beta_{6} \text { FirmSize }_{\mathrm{it}}+\text { Time Dummies }+\lambda_{\mathrm{i}}+\varepsilon_{\mathrm{i}, \mathrm{t}}
\end{gathered}
$$


where DState $_{i, t}$ is a dummy variable that equals 1 if the amount of state-owned shares is greater than the median value. We expect the coefficient on the interaction term between DState $_{i, t}$ and Leverage $_{i t-1}$ will be positive if the banks are more willing to lend to firms with greater state ownership.

\section{Summary Statistics and Results}

\subsection{Summary Statistics}

The sample used in this study consists of 1,203 firms listed on the Shanghai Stock Exchange or the Shenzhen Stock Exchange in China during 1991 - 2004. The firms in the financial sector are excluded from the sample in order to make the sample more homogenous. Our final sample is an unbalanced panel that consists of 5,999 firm-year observations. Since Growth is calculated based on the previous three years' data, the sample size is smaller (4186) for models that use Growth as an independent variable. The data are from the China Stock Market and Accounting Research Database (CSMAR). Table 1 provides summary statistics of the key variables.

[Table 1 here]

As can be seen from Table 1, the mean of the ratio of net investment to fixed assets is 0.341 , which is much higher than that reported in western literature (e.g., 0.17 in Canada, Aivazian et al., 2005). The sample average Tobin's Q is 1.231 and the standard deviation is 0.731 . The average growth rate is $43.2 \%$. The growth rate indicates strong growth opportunities for Chinese firms over our sample period. The mean of the ratio of bank loans to total assets is 0.223 , which suggests that there is a significant reliance on bank loan finance by Chinese listed firms.

The correlation matrix of the variables is presented in Table 2. As can be seen, all the correlation coefficients are less than absolute 0.46 , which suggests that multicollinearity is not a serious problem in the sample. Leverage is negatively and significantly related to investment, which provides some preliminary evidence of an 
inverse relation between investment and leverage.

[Table 2 here]

\subsection{Empirical Results}

The results of our baseline models are provided in Table 3. As can be seen from the table, the coefficients on Leverage are negative in all regressions and are statistically significant in 7 of the 9 regressions (Columns 4 and 6 being the exceptions). This result contrasts with other studies that argue that state-owned banks do not impose discipline on firms (Kornai et al., 2003). In other words, the listed firms do take their outstanding bank loans into account when making investment decisions. The significant coefficients on the Leverage variable range from -0.17 to -0.413 and this suggests that a 0.1 increase in leverage will reduce the investment to capital ratio by 0.017 to 0.0413 . Tobin's $Q$ and Growth are positively and significantly associated with the investment, which echoes the findings by Aivazian (2005). This indicates that firms with better growth prospects tend to invest more.

\section{[Table 3 here]}

The interaction term between the leverage and growth/performance measures is the key variable in the analysis. The interaction term allows us to examine how the banks' bail out policies affect the leverage and investment links in low growth (or poorly performing) firms. As can be seen from Column 8 in Table 3, the coefficient of the interaction term between DLoss and Leverage is positive and statistically significant at the $1 \%$ level, suggesting that leverage has a weaker negative impact on investment for loss making firms. The coefficient on the interaction term between DGrowth and Leverage is also positive and statistically significant at $1 \%$ level (Column 5). The coefficient on the interaction term between Leverage and DTobin'sQ is, however, statistically insignificant (Column 2). Overall, the results are consistent with our expectation that state-owned banks are obliged to provide a helping hand to low growth and poorly performing state-owned firms due to political goals and soft budget 
constraints. The result is opposite to the findings in developed countries (e.g., Lang et al., 1996; Aivazian et al., 2005), which find that the negative relation between leverage and investment is stronger for lower growth firms. As Jensen (1986) and Stulz (1990) point out, the negative relation between leverage and investment could be beneficial for shareholders of low growth and poorly performing firms because the outstanding debt limits managerial discretion over free cash flow. However, in China's case, we find that the negative relation between leverage and investment is significantly weaker for low growth and poorly performing firms than for high growth and better performing firms. These findings are consistent with the hypothesis that the state-owned banks in China impose fewer restrictions on investment spending by low growth and poorly performing listed firms. This offsets the potential disciplinary effect of leverage and creates an overinvestment bias in these firms.

The interaction term between state ownership and leverage is another key variable of our analysis. This allows us to capture how the banks' positive biases towards stateowned firms affect the leverage and investment links. As shown by Columns 3 and 9 in table 3, the interaction terms between DState $_{i, t}$ and Leverage $_{i t-1}$ are positive and significant at $5 \%$ in models where Tobin'sQ and Accounting Performance (Cash Flow) are used as the performance measures. DState $_{i, t} *$ Leverage $_{i t-1}$ is positive but statistically insignificant in the model where Growth is used as the performance measure. Overall, our results suggest that the negative relation between leverage and investment is weaker for firms with a higher level of state shareholding. The results are consistent with the hypothesis that the state-owned banks are more lenient in their lending to firms with greater state ownership.

Regarding the other control variables, the coefficients on Sale have a positive and significant effect on investment. The coefficients on State are negative but are not significant (except at the 0.10 level in columns 3 and 9). The results are consistent with the results obtained by Cull and $\mathrm{Xu}$ (2006), who find that state-owned firms tend to have 
a lower re-investment rate than private firms. Larger size firms (Firm Size) and firms with good performance (CashFlow) invest more.

\subsection{Instrumental Variables (IV) and Two-Stage Least Square Estimation}

Our results are likely to suffer from endogeneity problems because leverage is endogenously determined by firms rather than exogenously given (Aivazian et al., 2005). Given that a firm's leverage decision is likely to be correlated with investment opportunities, leverage will be correlated with the error terms in our investment models and its estimates will be biased if there are some common factors that affect leverage and investment opportunities but are omitted from the investment models. The fixed effect estimation partially alleviates this problem by eliminating the unobservable and timeinvariant firm characteristics. However, it is still possible that the managers reduce leverage in anticipation of future investment opportunities so that we observe a negative relation between leverage and investment. We therefore adopt a two-stage instrumental variable approach to deal with the endogeneity problem pertaining to the relations between leverage and investment. In the first stage, we estimate a firm's leverage decision and obtain a predicted leverage level for each firm. In the second stage, we use the predicted leverage level as a generated instrument variable for leverage and then reestimate the investment models.

In estimating a firm's leverage choice, we follow the recent literature and use a variety of instrumental variables. First, we follow Aivazian et al. (2005) and Molina (2005) and use Tangibility, defined as the proportion of the value of tangible assets to total assets, as an instrumental variable. Tangibility is potentially a good instrumental variable because it tends to reduce bankruptcy costs and therefore increases the use of leverage. Furthermore, Tangibility is unlikely to be correlated with a firm's investment opportunities (Aivazian et al., 2005). Second, the literature suggests that the non-debt tax shield (NDTS), the tax deduction for depreciation, is a potentially important determinant 
of leverage choice. DeAngelo and Masulis (1980) point out that non-debt tax shields are substitutes for the tax benefits of debt financing and a firm with larger non-debt tax shields is therefore more likely to use less debt. Using data from 1200 listed companies in China, Huang and Song (2006) find strong empirical evidence to support this theoretical prediction. Following Huang and Song (2006), we use depreciation and amortization scaled by total assets to proxy for NDTS, which is employed as an instrumental variable in our analysis. Third, Myers (1977) argues that firms can match the maturities of their assets and liabilities to reduce underinvestment problems, suggesting a positive link between the asset maturity and the use of long term debt. Asset Maturity is therefore used as an instrumental variable by Johnson (2003) and Billett et al. (2007) in their system of leverage, growth and maturity equations. Following Guedes and Opler (1996), we use Asset Maturity as an additional instrumental variable. We expect a positive link between the asset maturity and the use of bank loans, the main source of long term debt to firms. Fourth, we use the Earnings Volatility measure, defined as the standard deviation of EBIT/total assets over past three years, as an additional instrumental variable. As Bradley et al. (1984) and Johnson (2003) point out, firms with greater earnings volatility should have lower leverage. We therefore expect a negative link between Earnings Volatility and leverage. Lastly, we follow Grullon et al. (2006) and use average industry leverage as an instrumental variable. The literature (e.g., Bradley et al., 1984; Grullon et al., 2006) suggests that firms' leverage decisions are heavily influenced by the leverage ratio of industry peers since firms in the same industry tend to share commonalities in the factors that affect their capital structure. Thus, the average industry leverage should be a reasonably good instrumental variables of the leverage for a specific firm (Grullon et al., 2006).

We model a firm's leverage decision as a function of the instrumental variables as well as all the control variables in the investment decision model, with all the variables lagged one year to those used in the investment regressions. Consistent with our 
expectation, most instrumental variables enter the first stage regressions significantly and with their expected signs. For instance, NDTS is negatively and statistically significantly (at the $5 \%$ level) associated with the leverage ratio; Asset Maturity is positively and statistically significantly (at the $5 \%$ level) associated with the leverage ratio; Earning Volatility is negatively and statistically significantly (at the $5 \%$ level) associated with the leverage ratio; and Industry Average Leverage is positively and statistically significantly (at the $1 \%$ level) associated with the leverage ratio. Tangibility does not enter the first stage regressions significantly. We conduct an F-test of the exogenous IV variables in the first-stage regressions. The null hypothesis of the test is that the instruments do not explain differences in corporate leverage. We reject the null hypothesis at the $1 \%$ level in all model specifications. For brevity, the first-stage regressions are not reported but are available from the authors upon request. We obtain the fitted values of leverage and use them as generated instruments for Leverage and then re-estimate our investment models. The results of the instrumental variable estimation are reported in Table 4.

[Table 4 here]

As we can see from the table, the coefficients on Leverage are negative and are statistically significant. The coefficients range in value from -0.993 to -1.412 . Consistent with our previous findings, Tobin's $Q$ and sales growth are positive and are significant in columns 1, 2, 3, and 5. The interaction term between DLoss and Leverage $(\mathrm{b}=0.542, \mathrm{p}$ $<0.01)$ is also positive and statistically significant at the $1 \%$ level. The coefficient on the interaction term between DGrowth and Leverage is positive and statistically significant at the $5 \%$ level $(b=0.207, p<0.05)$, though the coefficient of the interaction terms between Leverage and DTobin'sQ is statistically insignificant. In addition, the interaction of DState and Leverage is positively and statistically significant at the $1 \%$ level (the coefficients range from 0.527 to $0.561, \mathrm{p}<0.01$ ). All these results confirm our findings from Table 3 that leverage has a weaker negative impact on investment for poorly performing firms, loss making firms, and state-controlled firms. Our results are therefore 
robust after dealing with the issue of endogeneity.

In addition, the IV coefficients are somewhat larger than the OLS coefficients, indicating the existence of potential measurement error, which would tend to "attenuate" the coefficient estimate toward zero (Laeven and Levine, 2007; Rajan and Subramanian, 2005). It is also worth noting that our main results do not depend on instrumentation, although the latter increases the significance and magnitude of the coefficients. In fact, this is a regular finding in the finance and growth literature (e.g., Molina, 2005; Laeven and Levine, 2007; Laeven and Woodruff, 2007; Barth et al., 2008). It should also be noted that in our fixed effect models without instrumentation, there is essentially no or very small negative correlations between leverage and investment for low-growth and poorly performing firms, which indicates the complete absence of monitoring effects. However, in the IV estimates, there is a significant negative relation between leverage and investment for these firms. The IV results suggest that there are some investment restrictions from the banks, although they are much weaker than those of the high-growth and well performing firms. Nevertheless, the results from both estimation methods indicate that the state-owned banks are more lenient in their lending to low growth and poorly performing firms than the high growth and well-performing firms.

\subsection{Alternative Explanations and Additional Robustness Tests}

Tables 3 and 4 show that the interaction terms between DGrowth ${ }_{i, t}$ and Leverage and DLoss and Leverage are significantly positive. We interpret our findings by a partial efficiency story in which the state banks successfully monitor firms that perform well (see the negative debt-investment correlation) but impose fewer constraints on investment for poorly performing firms and firms with greater state ownership. Nevertheless, there are also two possible alternative explanations. The first explanation (explanation A) is that state banks are fully (privately) inefficient in that the negative leverage-investment relation reflects the state's desire to "bail-out" firms rather than 
bank monitoring. One possible cause for the positive interaction terms between DGrowth $_{i, t}$ and Leverage, and DLoss and Leverage, is the existence of a cap on the extent of bailout to poorly performing firms. As a result, most of the poorly performing firms show similar leverage levels because they are close to a bailout cap imposed by the state-owned banks. On the other hand, state banks can also be fully (privately) efficient (explanation B). In this case, the positive interactions terms can be caused by the fact that the low growth firms essentially have very little investment so that the monitoring actions of bank financing are unlikely to show up in investment. Our previous finding about the positive interactive term between DState and Leverage already lends us some confidence that explanation i may not be the case. This is because under explanation A, the investment-leverage link would be even stronger for firms with greater state ownership if the tendency to bail out state firms in times of trouble is even higher. In contrast, we find that the investment-leverage link is weaker for state controlled firms. Nevertheless, in order to test these possibilities more directly, we divide sample firms into poorly performing and out-performing by using the mean value of Growth and CashFlow $_{i, t}$ respectively and then test the equality of the variation of Leverage and Investment between the poorly performing firms and the out-performing firms. Under the fully inefficient story, the variation in leverage will be smaller in the sample of poorly performing firms than in the out-performing firms. Under the fully efficient story, the variation in investment will be smaller in the poorly performing firms than in the out-performing firms because of the limited investment opportunities.

Results are reported in Table 5.

\section{[Insert Table 5]}

As can be seen from the table, the standard deviations of leverage for the bottom and top performing firms are not statistically different (in fact the standard deviations for the poor performers are actually slightly greater than for the top performers) Thus, explanation $\mathrm{A}$ is rejected by the variance comparison tests. This evidence echoes our 
previous findings and suggests that the fully inefficient (explanation A) explanation is not appropriate in our context. Furthermore, we find a similar pattern that the standard deviations of investment for the bottom performing firms are actually greater than those of the upper performing firms. Thus, explanation B is rejected by the variance comparison tests. This helps us rule out the fully efficient (explanation B) explanation.

Second, there is likely to be significant heterogeneity in firms' investment behaviors and banks' lending behaviors because of differences in industry structures. As Parrino (1997) points out, by filtering out the common factors within an industry such as shocks that are beyond managers' control, relative performance evaluation (RPE) provides more precise information about a firm's performance. We use industry-adjusted variables, calculated as the difference between a firm's own characteristics and the industry average value, to filter out the industry effect. The results, reported in Table 6, are very similar to our previous findings. The coefficients on Leverage remain negative and statistically significant in models where sales growth and financial performance are used as the performance measures. Consistent with our previous findings, Tobin'sQ and Growth are positively and significantly associated with investment, suggesting that firms with better growth prospects tend to invest more. The coefficient on the interaction term DLoss and Leverage is positive and statistically significant at the $5 \%$ level. The coefficient on the interaction term between DGrowth and Leverage is positive but statistically significant only at the $10 \%$ level. The coefficient on the interaction between Leverage and DTobin'sQ is statistically insignificant. Similarly, DState $_{i, t} *$ Leverage $_{i t-1}$ are significantly positive in models where Tobin'sQ and Accounting Performance (Cash Flow) are used as the performance measures; a positive but statistically insignificant coefficient is shown when Growth is used as the performance measure. Our results are therefore robust to dealing with the issue of industry heterogeneity.

[Table 6 here] 


\section{Conclusion}

This study examines the relations between leverage and investment among China's listed firms where banks are state owned. We offer three main findings. First, there is a negative relation between leverage and investment. This result indicates the existence of a debt overhang problem even when banks are state owned rather than privately owned. Second, the negative relation between leverage and investment is weaker in firms with low growth opportunities and poor operating performance than for firms with high growth opportunities and good operating performance. Third, the negative relation between leverage and investment is weaker in firms with a higher level of state shareholding than in firms with a lower level of state shareholding. Overall, this result is consistent with the hypothesis that the state-owned banks in China tend to impose less restrictions on the capital expenditure investments of low growth (and poorly performing) listed firms and also for firms with a high state ownership. To the extent that low growth and poorly performing firms tend to have fewer profitable investment projects than high growth and better performing firms, our study suggests that the political obligation of the state-owned banks to support ailing firms makes them unable to play a monitoring and disciplining role in preventing overinvestment by low growth and poorly performing firms. Furthermore, prior studies have documented that Chinese listed firms with greater state shareholding tend to be associated with lower corporate performance (Xu and Wong, 1999; Sun and Tong, 2003). The more lenient lending policies on the part of state owned banks also create an over-investment bias in these firms. Our study therefore provides some evidence on how state ownership of banks creates distortions in firms' real investment behaviors via the leverage-investment links.

\section{Table 1. Summary Statistics}

This table provides the summary statistics of the key variables included in our analysis.

Investment $_{i, t}$ is the ratio of net capital expenditure (capital expenditure minus depreciation) of firm $\mathrm{i}$ to total assets for the current year; Leverage $_{i, t-1}$ is the lagged one time period ratio of total bank loans to 
book value of total assets. Tobin' $s Q_{i, t-1}$ is the lagged one time period Tobin's $Q_{\text {for firm }} i$ at time $t$; Growth is the ratio of net sales in the current year to the average net sales over the previous three years. CashFlow $_{i, t}$ is the ratio of the operating cash flow of the firm to lagged one time period total assets; Sale $_{i, t-1}$ is the lagged one time period ratio of net sales of the firm to net fixed assets. State $_{i, t}$ is a dummy variable equals one if the firm $i_{\text {at time }} t_{\text {is state controlled; }}$ Firm Size $e_{i, t}$ is measured by the natural logarithm of total assets

\begin{tabular}{|c|c|c|c|c|c|c|}
\hline & $\mathrm{N}$ & Tean & Median & Standard & ation & Min \\
\hline estment $_{t}$ & 5999 & 0.341 & 0.148 & 0.566 & -0.100 & 4.487 \\
\hline $\sin s Q_{t-1}$ & 5999 & 1.231 & 1.048 & 0.731 & 0.267 & 8.569 \\
\hline 'erage $_{t-1}$ & 5999 & 0.223 & 0.211 & 0.132 & 0.000 & 0.830 \\
\hline swth & 4186 & 0.432 & 0.278 & 1.034 & -2.312 & 23.122 \\
\hline$e_{t-1}$ & 5999 & 2.297 & 1.714 & 1.869 & 0.120 & 9.798 \\
\hline shFlow & 5999 & 0.072 & 0.065 & 0.084 & -0.492 & 0.967 \\
\hline$t e_{t}$ & 5999 & 0.363 & 0.000 & 0.481 & 0.000 & 1.000 \\
\hline$m$ Size $_{t}$ & 5999 & 20.964 & 20.901 & 0.922 & 18.073 & 26.85 \\
\hline
\end{tabular}




\section{Table 2. Correlation matrix}

This table reports the correlation coefficients of the key variables included in our analysis.

Investment $_{i, t}$ is the ratio of net capital expenditure (capital expenditure minus depreciation) of firm i to total assets for the current year; Leverage $_{i, t-1}$ is the lagged one time period ratio of total bank loans to book value of total assets. Tobin's $Q_{i, t-1}$ is the lagged one time period Tobin's $Q_{\text {for firm }} i$ at time $t$; Growth is the ratio of net sales in the current year to the average net sales over the previous three years. CashFlow $_{i, t}$ is the ratio of the operating cash flow of the firm to lagged one time period total assets; Sale $_{i, t-1}$ is the lagged one time period ratio of net sales of the firm to net fixed assets. State $_{i, t}$ is a dummy variable equals one if the firm $i_{\text {at time }} t$ is state controlled; Firm Size $e_{i, t}$ is measured by the natural logarithm of total assets

\begin{tabular}{|l|l|l|l|l|l|l|l}
\hline & Investment $^{i, t}$ & Tobin's Q & & & \\
i,t-1 & Leverage $^{i, t-1}$ & Growth $^{i, t}$ & Sales & \\
\hline
\end{tabular}

\begin{tabular}{|l|l|l|l|l|l|l|}
\multicolumn{9}{l}{ State ${ }^{i, t}$} & & & & \\
\hline Investment $^{i, t}$ & 1 & & & & & \\
\end{tabular}

\begin{tabular}{|l|l|l|l|l|l|l|l|}
\hline Tobin's Q ${ }^{, t-1}$ & $0.061^{* * *}$ & 1 & & & & \\
\hline
\end{tabular}

\begin{tabular}{|l|l|l|l|l|l|l|}
\hline Leverage $^{t-1}$ & $-0.0347 * * *$ & $-0.0163 * *$ & 1 & & & \\
\hline
\end{tabular}

\begin{tabular}{|l|l|l|l|l|l|l|l|}
\hline Growth & $0.1378^{* * *}$ & $0.0439 * * *$ & $0.0286^{*}$ & 1 & & \\
\hline
\end{tabular}

\begin{tabular}{|c|c|c|c|c|c|c|}
\hline Sales & $0.1555^{* * *}$ & $-0.0555^{* * *}$ & $-0.0616^{* * *}$ & $0.0316^{*}$ & 1 & \\
\hline Cash flow ${ }^{t}$ & $0.2607 * * *$ & $0.0572 * * *$ & $-0.1934 * * *$ & $0.2707 * * *$ & $0.0231 * * *$ & 1 \\
\hline te & $-0.0785 * * *$ & $-0.1407 * * *$ & $-0.0618 * * *$ & $-0.0527 * * *$ & $-0.0381 * * *$ & $0.0548 * * *$ \\
\hline n Size & $0.0562 *$ & $-0.4567 * * *$ & $0.0387 * * *$ & $0.0987 * * *$ & 0.0646 & $0.2345^{* * *}$ \\
\hline
\end{tabular}

\section{Table 3. The Relation between Bank Loan and Investment in China (Firm} Fixed Effect Models)

This table reports the estimates obtained from the firm fixed effect models. The dependent variable is Investment $_{i, t}$ as defined in Table 1. Tables 1-3 use Tobin's Q as the performance measure, Tables 4-6 use sale growth as the performance measures. Tables 7-9 use accounting performance as the performance measure.

\begin{tabular}{|c|c|c|c|c|c|}
\hline & Tobin's Q Performance & Sale Growth Performance \\
Accounting Performance & $(5)$ & (6) \\
\hline
\end{tabular}


(7)

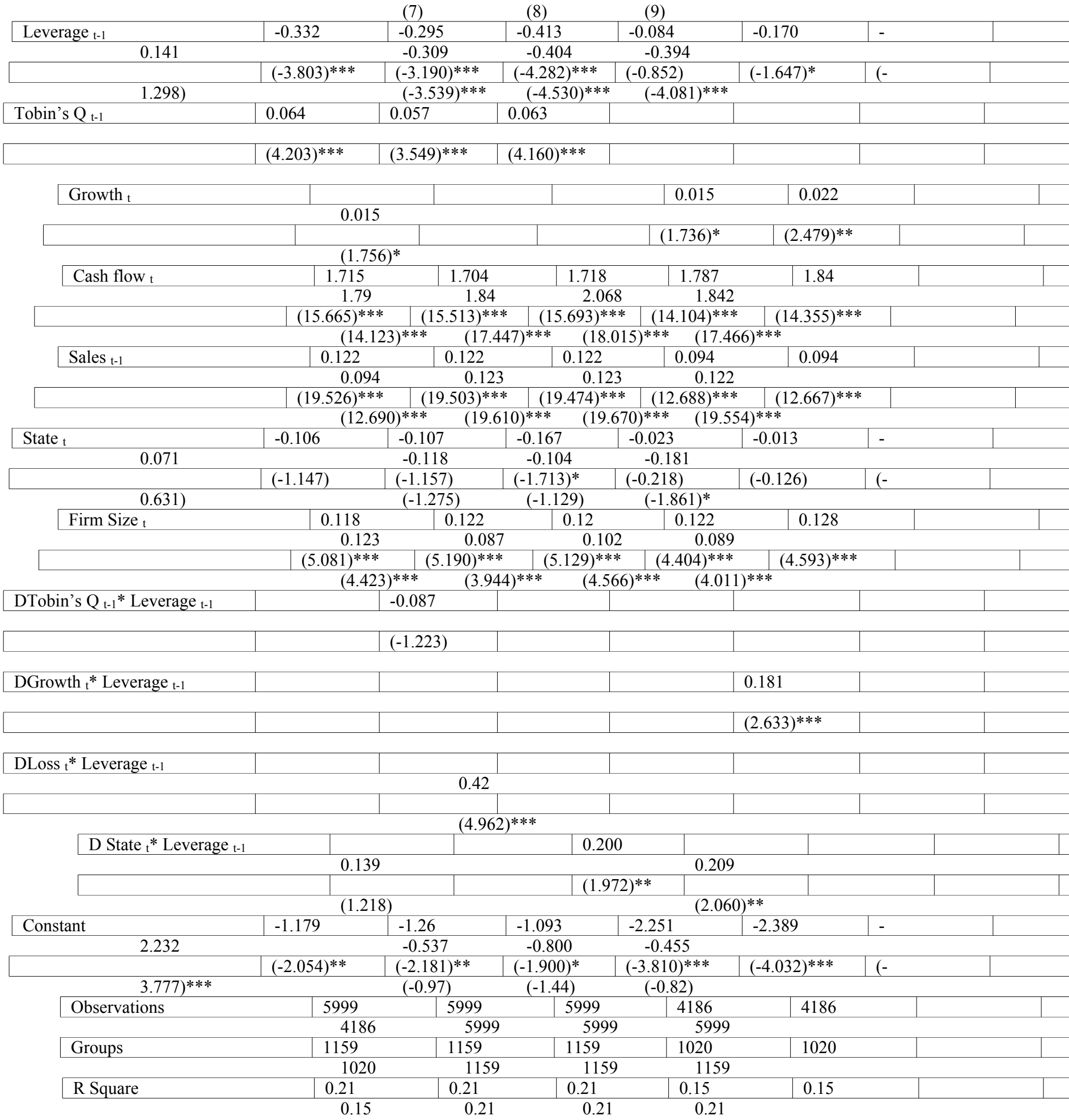

Table 4. The Relation between Bank Loan and Investment in China (Instrumental Variable Models)

This table reports the estimates obtained from the firm fixed effect models. The dependent variable is Investment $_{i, t}$ as defined in Table 1. Tables 1-3 use Tobin's Q as the performance measure, Tables 4-6 use sale growth as the performance measures. Tables 7-9 use accounting performance as the performance measure. 


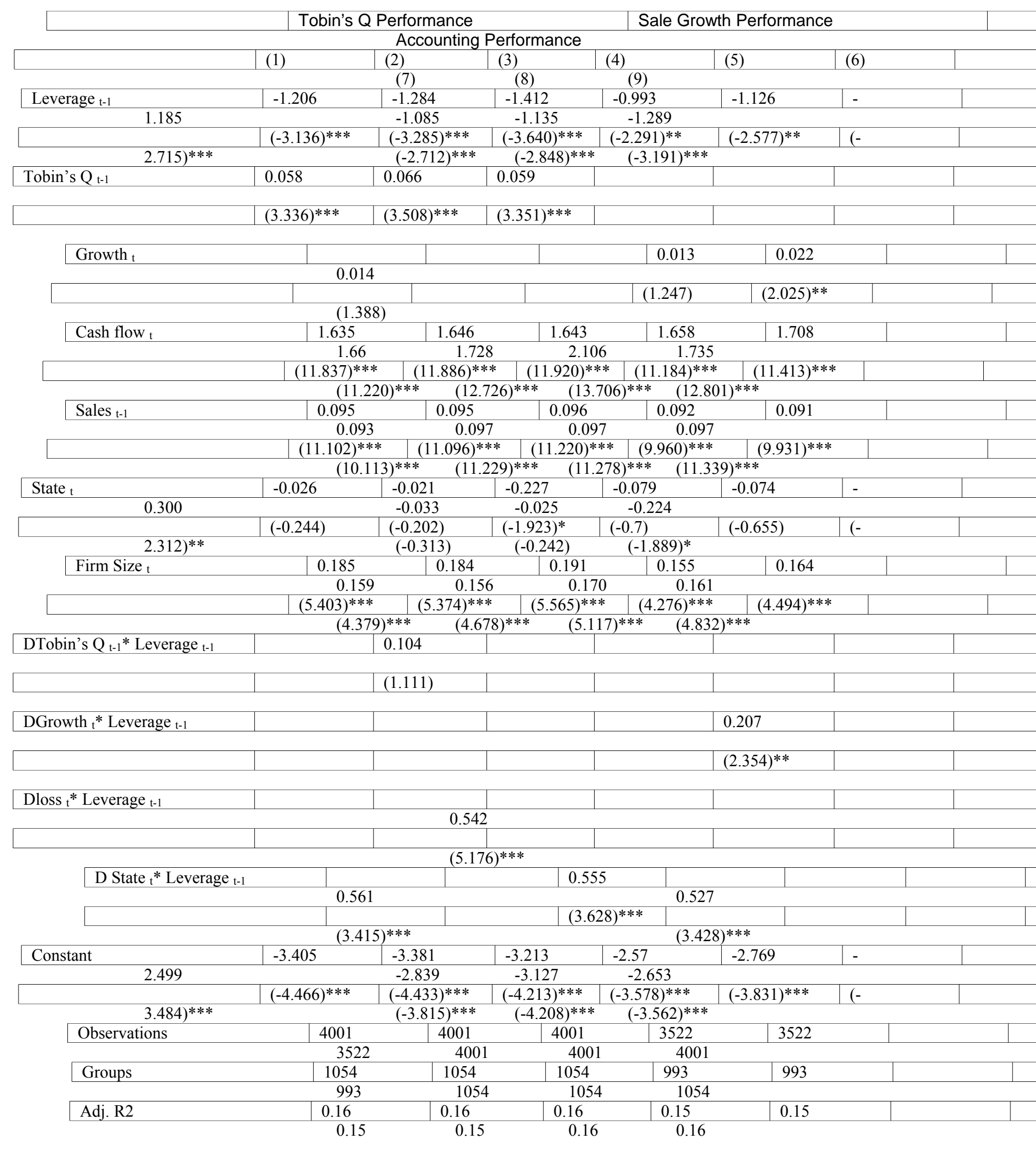




\section{Top Performing Firms}

This table reports the variance tests of leverage and investment between bottom and top performing firms. Investment and leverage are defined in Table

Variance test of Leverage

\begin{tabular}{|c|c|c|c|c|c|}
\hline & Classified by Sale & Growth & Classified & $\mathrm{cou}$ & \\
\hline & Performance & & & & \\
\hline & Mean (Leverage) & Standard Deviatio & (Leverage) & & \\
\hline$(\mathrm{Le})$ & Standa & Ird Deviation (Lever & & & \\
\hline Bottom & 0.2510502 & 0.1375996 & 0.2 & & \\
\hline & & 0.1342225 & & & \\
\hline Top & 0.2467677 & 0.1332412 & & & \\
\hline & & 0.1238487 & & & \\
\hline & atio test & tandard deviation ra & $0>1$ & & \\
\hline P-value & & 0.924 & & 1.0 & \\
\hline
\end{tabular}

\section{Variance test of Investment}

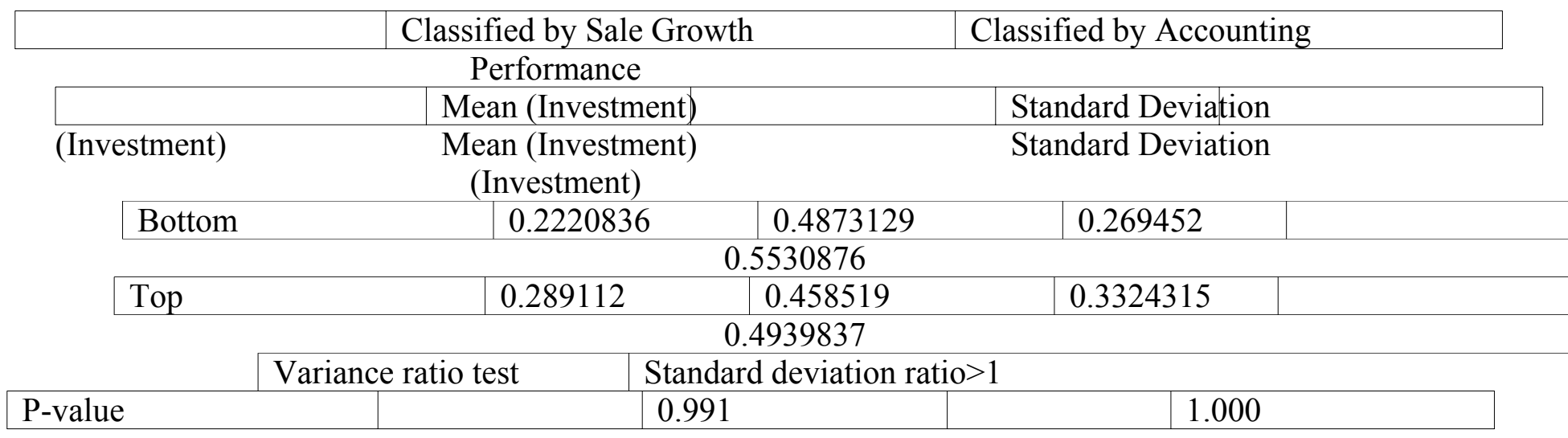

Table 6. The Relation between Bank Loan and Investment in China (Industry Mean Adjusted)

This table reports the estimates obtained from the fixed effect models using industry mean adjusted values. . Tables 13 use Tobin's Q as the performance measure, Tables 4-6 use sale growth as the performance measures. Tables 7-9 use accounting performance as the performance measure.

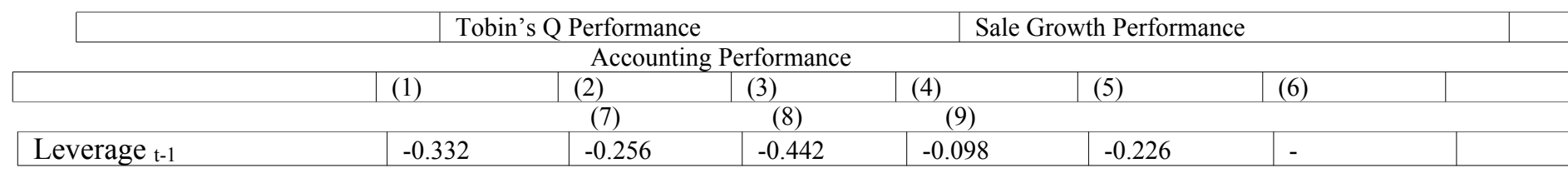




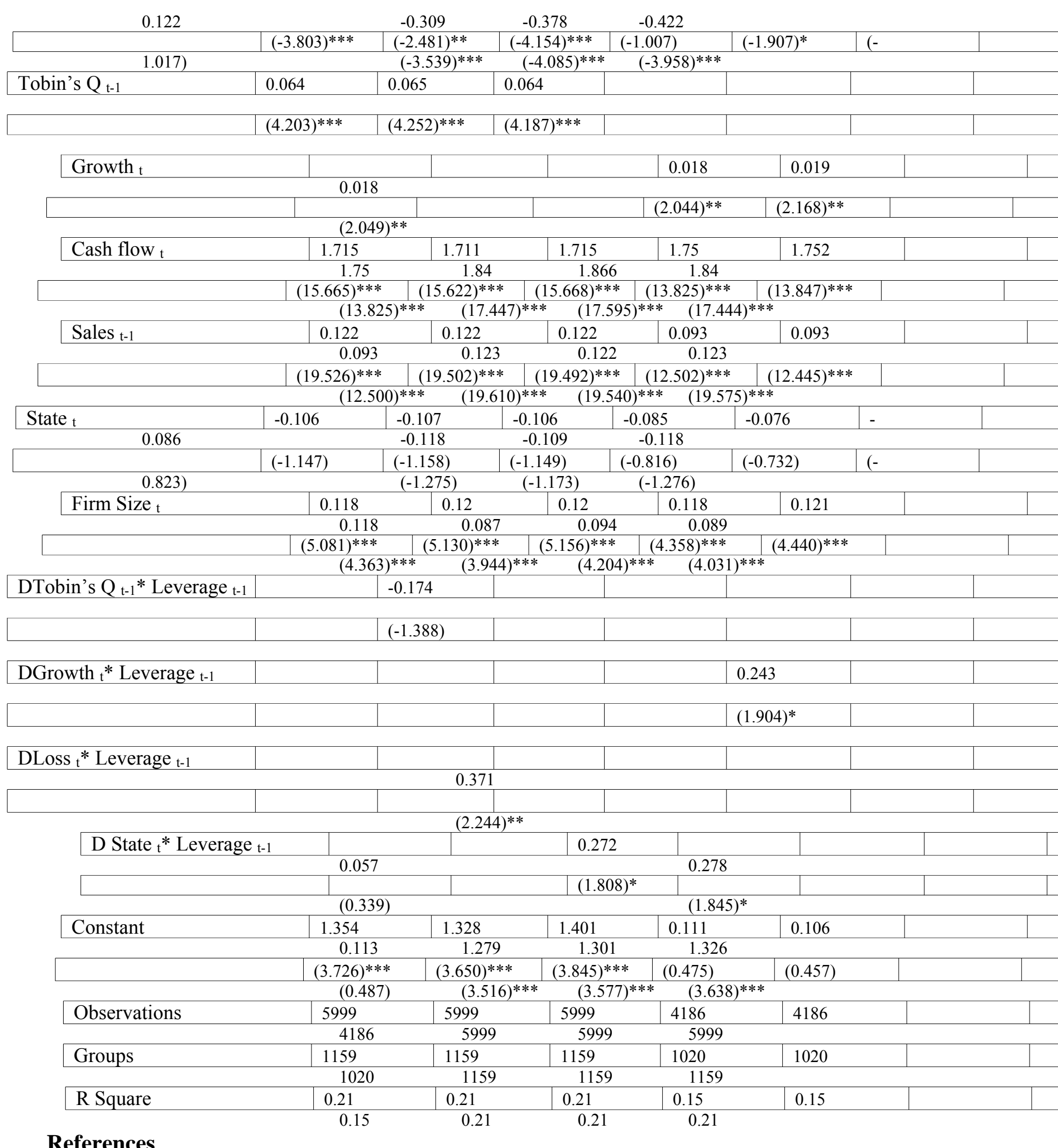

Ahn, S., Denis, D. J., Denis, D. K., 2006. Leverage and investment in diversified firms. Journal of Financial Economics 79, 317-337. 
Aivazian V., Ge, Y., Qiu, J., 2005. The impact of leverage on firm investment: Canadian evidence. Journal of Corporate Finance 11, 277-291.

Aivazian V., Ge, Y., Qiu, J., 2005. Can corporatization improve the performance of stateowned enterprises even without privatization? Journal of Corporate Finance 11, 791808 .

Allen, F., Qian, J., Qian, M., 2005. Law, finance, and economic growth in China. Journal of

Financial Economics 77, 57-116.

Barth, J. R., Caprio, Jr., G., Levine, R., 2004. Bank supervision and regulation: what works best? Journal of Financial Intermediation 13, 205-248.

Barth, J., Lin C., Lin P., and Song F., 2008. Corruption in bank lending to firms:

Cross-country micro evidence on the beneficial role of competition and information sharing, Journal of Financial Economics, forthcoming.

Bai C., Qia L., Song F., 2003. Value of corporate control: Evidence from China's distressed firms . Unpublished mimeo, available on ssrn.com.

Beck T., Demirgüç-Kunt A., Maksimovic, V., 2004. Bank Competition and Access to Finance: International Evidence, Journal of Money, Credit and Banking 36, 627-648

Berger A. N., Udell G. F., (2002). Small business credit availability and relationship lending: the importance of bank organizational structure, Economic Journal 112, 32-55

Bertrand, M., Scholar A., Thesmar D., 2007. Banking deregulation and industry structure: evidence from the French banking reforms of 1985. Journal of Finance 62, 597-628.

Billett, M. T., King, T.-H., Maurer, D., 2007. Growth opportunities and the choice of leverage , debt maturity, and covenants. Journal of Finance 62, 697-730.

Bradley, M., Jarrell, G.A., Kim, E.H., 1984. On the existence of an optimal capital structure: Theory and evidence. Journal of Finance 39, 857-878.

Brandt, L., Li H. B., 2003. Bank discrimination in transition economies: Ideology, information or incentives? Journal of Comparative Economics 31, 387-413.

Byers, Steven S., Fields, L. P., Fraser, Donald R., 2008. Are corporate governance and bank monitoring substitutes: Evidence from the perceived value of bank loans, Journal of Corporate Finance, forthcoming.

Byrd D. J., Mizruchi M.S., 2005. Bankers on the board and the debt ratio of firms. Journal of Corporate Finance 11, 129-173

Cetorelli N., 2004. Real effects of bank competition, Journal of Money, Credit and 
Banking 36, 543-558

Chan, K., Wang, J.,Wei, K.C., 2004. Underpricing and long-term performance of IPOs in China

Journal of Corporate Finance 10, 409-430

Chen, G., Firth, M., Gao, D. N., Rui, O. M., 2006. Ownership structure, corporate governance, and fraud: Evidence from China. Journal of Corporate Finance, 12, 424-448

Chen, Z., Xiong, P., 2002. The illiquidity discount in China. Working paper, International Center for Financial Research, Yale University.

Cull, R., Xu, L.C., 2003. Who gets credits? The behavior of bureaucrats and state banks in allocating credit to Chinese state-owned enterprises. Journal of Development Economics 71, 533-559.

Cull, R., Xu, L.C., Zhu, T., 2007. Formal finance and trade credit during China's transition (April 1, 2007). World Bank Policy Research Working Paper No. 4204 Available at SSRN: http://ssrn.com/abstract $=980822$

DeAngelo, H., Masulis, R., 1980. Optimal capital structure under corporate and personal taxation. Journal of Financial Economics 8, 3-29.

Dinc, I.S., 2005. Politicians and banks: political influences on government-owned banks in emerging markets. Journal of Financial Economics 77, 453-479.

Delios A. Wu. Z.J. and Zhou N. 2006. A new perspective on ownership identities in China's listed companies. Management and Organization Review 2, 319-343

Diamond, D., 1984. Financial Intermediation and delegated monitoring, Review of Economic Studies 51, 393-414

Dobson, W., Kashyap, A. K., 2006. The contradiction in China's gradualist banking reforms. Brookings Papers on Economic Activity 2, 103-162.

Firth, M.; Fung, M.Y., Rui. O., 2006. Corporate performance and CEO compensation in China. Journal of Corporate Finance 12, 693-714.

González, V., and González, F., 2008. Influence of bank concentration and institutions on capital structure: New international evidence, Journal of Corporate Finance, forthcoming.

Grullon, G., Kanatas, G., Kumer, P., 2006. The impact of capital structure on advertising competition: An empirical study. Journal of Business 79, 3101-3124.

Guedes, J., Opler, T., 1996. The determinants of the maturity of corporate debt issues. Journal of Finance 51, 1809-1834. 
Harris, M., Raviv A., 1990. Capital structure and informational role of debt, Journal of Finance 45, 321-349

Huang, G., Song, F., 2006. The determinants of capital structure: Evidence from China. China Economic Review 17, 14-36.

Jensen, M.C., 1986. Agency costs of free cash flow, corporate finance, and takeovers. American Economic Review 76, 323-329.

Jensen, M.C. Meckling W.H., 1976. Theory of the firm: managerial behavior, agency costs, and ownership structure. Journal of Financial Economics 3, 305-360.

Johnson, S., 2003. Debt maturity and the effects of growth opportunities and liquidity risk on leverage. Review of Financial Studies 16, 209-236.

Kang J.K., Shivdasani A., 1995. Firm performance, corporate governance and top CEO turnover in China. Journal of Financial Economics, 38, 29-58

Krosznera R. S., Strahan P.E., 2001. Bankers on boards: Monitoring, conflicts of interest, and lender liability. Journal of Financial Economics 62, 415-452

Kee H., Pruitt, S.W., 1994. A simple approximation of Tobin's q. Financial Management $23,70-74$

Kornai, J, Maskin, E., Roland, G., 2003. Understanding the soft budget constraint. Journal of Economic Literature 41, 1095-1136.

Khwaja, A., Mian, A., 2005. Do lenders favor politically connected firms? Rent provision in an emerging financial market. Quarterly Journal of Economics 120, 1371-141.

Lang, L., Ofek, E., Stulz, R. M., 1996. Leverage, investment and firm growth. Journal of Financial Economics 40, 3-29.

La Porta, R., López de Silanes, F., Shleifer, A., 2002. Government ownership of banks. Journal of Finance, 57: 265-301.

Laeven, L., Levine, R., 2007. Corporate governance, regulation, and bank risk-taking, working paper, Brown University.

Laeven, L., Woodruff, C., 2007. The quality of the legal system, firm ownership, and firm size.

Review of Economics and Statistics 89, 601-614.

Lin, C., Su, D., 2008. Industrial diversification, partial privatization and firm valuation: Evidence from publicly listed firms in China. Journal of Corporate Finance, forthcoming. 
McConnell, J.J., Servaes, H., 1995. Equity ownership and the two faces of debt. Journal of Financial Economics 39, 131-157.

Modigliani, F., Miller, M.H., 1958. The cost of capital, corporation finance, and the theory of investment. American Economic Review 53, pp. 433-443.

Molina, C., 2005. Are firms underleveraged? An examination of the effect of leverage on default probabilities. Journal of Finance 60, 1427-1459.

Morck, R., Yueng, B., Yu, W., 2000. The information content of stock market: why do emerging

markets have synchronous stock price movement? Journal of Financial Economics 58, 215-20.

Myers, S., 1977. Determinants of corporate borrowing. Journal of Financial Economics 5, pp. 147-175.

Parrino, R., 1997. CEO turnover and outside succession: a cross-sectional analysis. Journal of Financial Economics 46, 165-197.

Pistor, K., Xu, C., 2004. Governing Stock Markets in Transition Economies Lessons from China. American Law and Economics Review, 7, 184-210

Qian, J., Strahan, P.E., 2007. How law and institutions shape financial contracts: the evidence from international data. Journal of Finance 62, 2803 - 2834

Rajan, R., Subramanian, A., 2005. What undermine aid's impact on growth? NBER Working Paper No. 11657

Sapienza, P., 2004. The effects of government ownership on bank lending. Journal of Financial Economics 72, 357-384.

Shleifer, A., Vishny, R. W., 1994. Politicians and firms. Quarterly Journal of Economics 109 (4), 995-1025.

Stulz, R.M., 1990. Managerial discretion and optimal financing policies. Journal of Financial Economics 26, 3-27.

Wong, S.M.L., 2006. China's stock market: The marriage between capitalism and socialism, Cato Journal 26, 389-424

Xu X., Wang Y., 1999. Ownership structure and corporate governance in Chinese stock companies. China Economic Review 10, 75-98.

Zarutskie R., 2006. The effects of bank competition on firm borrowing and investment. Journal of Financial Economics 37, 503-581 
